\title{
Productivity and Profitability of Baby Corn-hyacinth Bean Cropping System as Influenced by Nutrient Management Practices
}

\author{
R. Preetham ${ }^{1 *}$, K. Avil Kumar ${ }^{2}$, A. Srinivas ${ }^{2}$, A. Manohar Rao ${ }^{2}$ and T. Ram Prakash ${ }^{2}$ \\ ${ }^{1}$ Scientist and Head, Horticultural Research Station, Adilabad, India \\ ${ }^{2}$ PJTSAU, Rajendranagar, Hyderabad, India \\ *Corresponding author
}

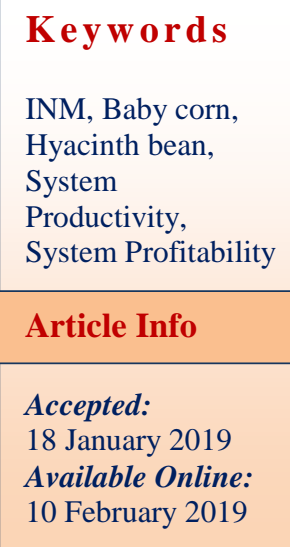

\section{Keywords}

INM, Baby corn, Hyacinth bean, System Productivity, System Profitability

\section{A B S T R A C T}

A field experiment was conducted at Horticultural Research Station, Adilabad during kharif and rabi seasons of 2015-16 and 2016-17 to study the effect of integrated nutrient management practices on system productivity, profitability and economics of baby cornhyacinth bean cropping system. The experiment was laid out in a randomized block design for baby corn during kharif, 2015 season with seven treatments comprised of $100 \%$ Recommended dose of fertilizer (RDF- 150:60:60 N, $\mathrm{P}_{2} \mathrm{O}_{5}$, and $\mathrm{K}_{2} \mathrm{O} \mathrm{kg} \mathrm{ha}{ }^{-1}$ ) $25 \% \mathrm{~N}$ supplemented through Farm Yard Manure (FYM) or vermicompost (VC) + 75\% RDF with or without soil application of Azospirillum and Bacillus megaterium@ $5 \mathrm{~kg} \mathrm{ha}^{-1}$ each, in addition to control (no fertilizer application) and replicated thrice. Manures and inorganic fertilizers, $\mathrm{P}_{2} \mathrm{O}_{5}$ and $\mathrm{K}_{2} \mathrm{O}$ (single super phosphate and muriate of potash) incorporated into the soil before sowing as per the treatments. Nitrogen (urea) was applied in three splits at 10, 25 and 40 DAS. Each main treatment was divided into four sub plots and the treatments of $100 \%$ RDF and 75\% RDF with or without Bradyrhizobium @ $500 \mathrm{~g} \mathrm{ha}^{-1}$ (seed treatment) were imposed for hyacinth bean in rabiseason and data of kharif, 2016 and rabi, 2015-16 and 2016-17 was analysed in split plot design. Integrated use of $25 \% \mathrm{~N}$ through VC, bio-fertilizers and 75\% RDF (inorganic) during kharif to baby corn and 100\% RDF along with Bradyrhizobium seed treatment to hyacinth bean during rabi realized higher system productivity, gross returns, net returns, system profitability over rest of the treatments of $100 \% \mathrm{RDF}$ with or without bio-fertilizers, $25 \% \mathrm{~N}$ through FYM with or without bio-fertilizers and $75 \% \mathrm{RDF}, 25 \% \mathrm{~N}$ through $\mathrm{VC}+75 \% \mathrm{RDF}$ and unfertilized control during kharif followed by $75 \%$ RDF with or without seed treatment with Bradyrhizobium and $100 \%$ RDF alone to rabi hyacinth bean.

\section{Introduction}

Adilabad is bestowed with good amount of rainfall, cotton and soybean are the important rainy season crops along with tomato, brinjal in this region. Growers mostly follow cultivation of cotton or soybean as monocropping and leave the field follow for remaining part of the year. Productivity of rainfed mono-cropping system in Northern Telangana Zone is very low and it is a high economic risk activity. 
Intensive natural resources mining, continuous degradation of natural resources (soil, water, vegetation) and practice of monocropping under conventional agricultural practice will not ensure farm productivity and food security (Ghosh et al., 2010). Emphasis needs to be given for increasing productivity levels besides diversification towards high value crops. Poor recycling of organic sources, application of high analysis fertilizers caused deficiency of several micro nutrients in soil and also lead to environmental pollution (Kumar, 2008).

In Northern Telangana Zone, maize is one of the main kharif crops. In recent times efforts were made to popularize baby corn speciality maize because of its nutritive value, demand in hotels. Baby corn is a potential crop that could improve the economic status of the farmers in India (Das et al., 2008) through earning foreign exchange as well as meeting local needs. Application of chemical fertilizers may assist in obtaining maximum production of baby corn but is leading to hazardous effect on the environment (Ranjan et al., 2013, Mahajan et al., 2007 and Dadarwal et al., 2009).

Dolichos bean is a legume crop which fits up well in the multiple cropping systems, which has multiple uses and also restores soil fertility. It is one of the main rabi crop in Karimnagar and Jagtial districts of Northern Telangana Zone. The extensive research on INM in different crops and cropping system has emphasized its importance in achieving production, economic and environmental sustainability. Addition of multiple cropping systems needs more nutrients for proper growth and development of each crop in sequence. For a sustainable crop production system, chemical nutrients removed by the crop must be replenished and physical condition of the soil maintained.
Balanced application of nutrients through any source is most important in increasing the agricultural productivity. Fertilizers have played a major role in replenishing the soil fertility and increasing the yield. But their escalating costs, stagnation in yields and the injudicious use is compelling to look for other alternatives. Secondly the use of chemical fertilizers (mainly NPK fertilizers) alone is leading to the deficiency of other nutrients particularly, the micronutrients. On the other hand, organics alone cannot meet the nutritional requirement of the crops as the nutrient contents in these are very low. Therefore, for sustained yields and to maintain the soil health, the integration of organic and inorganic is the viable alternative. However, due to the adverse effects of chemicals on ecosystem / environment and quality of produce, the concept of pure organic farming has also come up. However, organic farming can only be practiced in high value crops at selected places to improve their quality.

Keeping the above facts in view, the present investigation was undertaken to assess the productivity and economics of baby cornhyacinth bean cropping system with integrated use of manures, microbial cultures and inorganic fertilizers.

\section{Materials and Methods}

The experiment was conducted at horticultural research station farm, Adilabad during kharif, 2015 and 2016 and rabi seasons of 2015-16 and 2016-17. The experimental site is situated at an altitude of 264 meters above mean sea level on $79^{\circ} 56^{\prime}$ 03 " E longitude and $19^{\circ} 08^{\prime} 09^{\prime \prime} \mathrm{N}$ latitude. The experimental soil was sandy clay loam in texture, neutral in reaction, medium in available nitrogen, phosphorous and potassium. The soil belongs to the order Alfisol of shallow to medium depth. The 
experiment was laid out in a randomized block design for baby corn during kharif, 2015 season with seven treatments comprised of $25 \% \mathrm{~N}$ supplemented through farm yard manure (FYM) or vermicompost (VC) $+75 \%$ Recommended dose of fertilizer, (100\% RDF; 150:60:60 N, $\mathrm{P}_{2} \mathrm{O}_{5}$ and $\mathrm{K}_{2} \mathrm{O} \mathrm{kg} \mathrm{ha}{ }^{-1}$ ) with or without soil application of Azospirillum and Bacillus megaterium@ $5 \mathrm{~kg} \mathrm{ha}^{-1}$ each, and control (no fertilizer application), replicated thrice. Each main treatment was divided into four sub plots and the treatments $100 \% \mathrm{RDF}$, 75\% RDF, 100\% RDF + Bradyrhizobium @ $500 \mathrm{~g} \mathrm{ha}^{-1}$ (seed treatment) and 75\% RDF + Bradyrhizobium @ $500 \mathrm{~g} \mathrm{ha}{ }^{-1}$ (seed treatment) were imposed in rabi. Experimental Design for rabi, 2015-16, kharif, 2016 and rabi, 2016-17 was split plot.

\section{Babycorn}

Manures and fertilizers were applied as per the treatment. Azospirillum (nitrogen fixing bacterial formulation) and Bacillus megaterium (phosphorus solubilizing bacterial formulation) @ $5 \mathrm{~kg} \mathrm{ha}^{-1}$ was utilized for baby corn as per the treatments. G-5414 variety of baby corn which grows to height of 180-200 cm and matures within 5055 days was selected for testing. The crop was sown on $22^{\text {nd }}$ and $3^{\text {rd }}$ July in 2015 and 2016, respectively. Two seeds were dibbled hill ${ }^{-1}$ at a depth of 3-4 $\mathrm{cm}$ with a spacing of $60 \mathrm{~cm} \mathrm{x}$ $15 \mathrm{~cm}$. Gap filling was done on $7^{\text {th }}$ day after sowing and thinning was done on $14^{\text {th }}$ day after sowing. Atrazine @ $1.0 \mathrm{~kg}$ a.i ha ${ }^{-1}$ was applied two days after sowing to control the weeds. The field was maintained weed free condition by hand weeding at 15 and 30 DAS. Harvesting of the ears was done after observing 2-3 cm long silk emergence. Harvesting was continued from 58 to 68 DAS plot wise and yield in each plot at each harvest was recorded treatment wise. In all, three pickings were done in 11 days and summed up to work out yield ha ${ }^{-1}$.

\section{Hyacinth bean}

Bradyrhizobium (nitrogen fixing bacterial formulation)@ $900 \mathrm{~g} \mathrm{ha}^{-1}$ was utilized for seed dressing of hyacinth bean as per the treatments. Fertilizers were applied as per the treatment. Arka Jay variety, vegetable type bean with excellent cooking quality was selected for testing. The crop was sown on $10^{\text {th }}$ and $6^{\text {th }}$ October in 2015 and 2016, respectively. One seed was dibbled hill $^{-1}$ at a depth of 3-4 cm with a spacing of $45 \mathrm{~cm} \times 20$ $\mathrm{cm}$. Gap filling was done on $7^{\text {th }}$ day after sowing. The fresh pods were harvested at 80 , 100and 127 DAS. In all there were three pickings during rabi, 2015-16 and 2016-17.

Baby corn equivalent yield (BEY) and system productivity was calculated as detailed below:

Hyacinth bean yield $\mathrm{x}$ sale price of hyacinth bean

$\mathrm{BEY}=$

Sale price of baby corn

System productivity $\left(\mathrm{kg} \mathrm{ha}^{-1}\right.$ year $\left.^{-1}\right)=\mathrm{BEY}+$ Baby corn yield $\left(\mathrm{kg} \mathrm{ha}^{-1}\right)$

System productivity $\left(\mathrm{kg} \mathrm{ha}^{-1}\right.$ day $\left.^{-1}\right)=$

$$
\mathrm{BEY}+\text { Baby corn yield }\left(\mathrm{kg} \mathrm{ha}^{-1}\right)
$$

\section{5}

To find out the economic viability of the system, the cost of cultivation, gross returns, net returns and system profitability were worked out. The expenditure incurred from field preparation to harvest of baby corn and hyacinth bean was worked out and expressed as ₹ $\mathrm{ha}^{-1}$

The crop yield was computed $\mathrm{ha}^{-1}$ and the total income was worked out based on the market rate which was prevalent during the time of study. The following local prices were 
considered for computing gross monitory returns.

System net returns (Rs. ha ${ }^{-1}$ ) System profitability (Rs. ha ${ }^{-1}$ day $^{-1}$ ) = --------365

The data on observations were analyzed statistically by applying the technique of analysis of variance as outlined by Panse and Sukhatme (1978) for Randomized Block Design and for Split Plot design as suggested by Gomez and Gomez (1984). Statistical significance was tested by $\mathrm{F}$ test. Critical difference for treatment means was evaluated at 5 per cent level of probability $(\mathrm{P}=0.05)$.

\section{Results and Discussion}

\section{Production potential of baby corn-hyacinth bean cropping system}

\section{System productivity}

The economic yields of baby corn, hyacinth bean were converted into baby corn equivalent yields to compare different treatments. The baby corn equivalent yields were significantly influenced by the treatments given to kharif baby corn and succeeding hyacinth bean but not for their interactions.

Significantly higher system productivity of $3918 \mathrm{~kg} \mathrm{ha}^{-1} \mathrm{yr}^{-1}$ and $10.73 \mathrm{~kg} \mathrm{ha}^{-1}$ day ${ }^{1}$ (pooled mean data of two years) was realized due to application of $75 \% \mathrm{RDF}$ in conjunction with $25 \% \mathrm{~N}$ through $\mathrm{VC}$ and bio fertilizer (Azospirillum and Bacillus megaterium) to baby corn in kharif and due to residual effect on hyacinth bean during rabi. Least system productivity of $2272 \mathrm{~kg} \mathrm{ha}^{-1} \mathrm{yr}^{-1}$ and $6.22 \mathrm{~kg}$ $\mathrm{ha}^{-1}$ day $^{-1}$ was realized in unfertilized control treatment (Table 1).

Substitution of $25 \%$ of inorganic fertilizer N with organic manures (VC or FYM) showed higher system productivity over $100 \%$ RDF with or without bio fertilizer. Substitution of $25 \%$ RDN through VC or FYM might have supplied major nutrients as well as micro nutrients ensuring balanced plant nutrition, besides improving soil physical (Anil Kumar et al., 2002), chemical properties (Singh et al., 1980) and biological properties (Santhyet al., 1998) of soil resulting in favourable conditions for crop growth and development thereby resulting in higher cob and baby corn equivalent yield (Table 1) over other treatments.

Bio fertilizer (Azospirillum and Bacillus megaterium) when integrated with $25 \% \mathrm{~N}$ through organic manures and $75 \% \mathrm{RDF}$ or applied along with 100\% RDF realized higher system productivity over the treatments in which the bio-fertilizer was not combined. The promising effect of bio-fertilizers may be attributed to production of biologically active substances like vitamins, nicotinic acid, Indole-acetic acid, gibberellins etc., in better germination, root and shoot growth and fixation of atmospheric nitrogen. Secretion of growth promoting substances of Azospirillum and increased bacterial efficiency by Bacillus megaterium (Datta and Banik, 1997) combined together might have increased yield of baby corn and ultimately the system productivity.

Among the organic manures, use of $\mathrm{VC}$ along with $75 \%$ RDF with bio-fertilizers realized higher system productivity over FYM along with $75 \%$ RDF with or without bio fertilizer treatments (Table 1). Synergistic effect of VC along with bio-fertilizer may be attributed to promoting effect of micronutrient and growth regulators present in VC (Ranjanet al., 2013).

\section{Economics of baby corn-hyacinth bean cropping system}

\section{Gross and net returns}

The gross and net returns were significantly influenced by the direct and residual effect of 
treatments imposed to kharif baby corn and succeeding hyacinth bean but not by the interactions. Perusal of the pooled mean data of two years of economics of baby cornhyacinth bean cropping system revealed that, integration of $25 \% \mathrm{~N}$ through $\mathrm{VC}$ with $75 \%$ $\mathrm{RDF}$ along with bio-fertilizers resulted in an increase of gross and net returns to the tune of $23.97 \%$ and $26.91 \%$ over $100 \%$ RDF and $72.61 \%$ and $91.41 \%$ over un-fertilized control (Table 2).

Combined use of $100 \%$ RDF and biofertilizer resulted in an increase of gross and net returns (7.24\% and $9.32 \%$ ) over $100 \%$ $\mathrm{RDF}$ and $(49.32 \%$ and $64.88 \%)$ over unfertilized control.

Significantly higher gross and net returns (Rs. 3,58, 595 and Rs. 2,70, 250) were realized with the application of $75 \% \mathrm{RDF}$ integrated with $25 \% \mathrm{~N}$ through $\mathrm{VC}$ in conjunction with the bio-fertilizers (Azospirillum and Bacillus megaterium) over rest of the treatments of $100 \%$ RDF with or without bio-fertilizers, $25 \% \mathrm{~N}$ through FYM or VC integrated with $75 \%$ RDF and unfertilized control and was at par with $25 \% \mathrm{~N}$ through FYM integrated with $75 \%$ RDF along with bio-fertilizers (Table 2). All the treatments imposed recorded significantly higher gross and net returns over un-fertilized control.

Substitution of $25 \% \mathrm{~N}$ through organic manures (VC and FYM) resulted in significantly higher gross and net returns over application $100 \%$ RDF through inorganic sources and un-fertilized control during both the years of study. Among the organic manures, use of $\mathrm{VC}$ resulted in higher gross and net returns over FYM.

Use of bio-fertilizers along with 100\% RDF resulted in the realization of significantly higher gross and net returns over 100\% RDF alone and unfertilized control.

\section{System profitability}

The system profitability was highest (Rs. $740.4 \mathrm{ha}^{-1}$ day $^{-1}$ ) with application of $75 \%$ $\mathrm{RDF}$ in conjunction with $25 \% \mathrm{~N}$ through VC and bio-fertilizer, due to direct and residual effect of the treatment imposed to baby corn during kharif and hyacinth bean during rabi (Table 2).

Lowest system profitability of Rs. $386.8 \mathrm{ha}^{-1}$ day $^{-1}$ was realized with unfertilized control. All the organic treatments $(25 \% \mathrm{~N}$ through FYM or VC) integrated with $75 \%$ RDF with or without bio-fertilizers realized higher system profitability over the use of $100 \%$ recommended dose of inorganic fertilizers with or without use of bio-fertilizer and unfertilized control.

Among the organic treatments use of $25 \% \mathrm{~N}$ through VC integrated with $75 \%$ RDF with or without use of bio-fertilizer realized higher system profitability over respective use of FYM in place of VC. Use of bio-fertilizer (Azospirillum and Bacillus megaterium) along with $100 \%$ RDF realized higher system profitability over $100 \% \mathrm{RDF}$ alone and unfertilized control.

Higher system profitability is due to significant higher economic yields, higher gross returns and net returns.

Based on the above results it can be concluded that, conjunctive use of $25 \% \mathrm{~N}$ through VC and $75 \%$ RDF along with soil application of bio-fertilizers (Azospirillum and Bacillus megaterium) @ $5 \mathrm{~kg} \mathrm{ha}^{-1}$ for baby corn and application of $100 \%$ RDF with Bradyrhizobium seed treatment to hyacinth bean during rabi found better for realization of maximum yield, maximum monetary returns and higher system productivity and profitability. 
Table.1 Effect of integrated nutrient management practices on system productivity ( $\left.\mathrm{kg} \mathrm{ha}^{-1} \mathrm{year}^{-1} \mathrm{and} \mathrm{kg} \mathrm{ha}^{-1} \mathrm{day}^{-1}\right)$ of baby cornhyacinth bean cropping system

\begin{tabular}{|c|c|c|c|c|}
\hline \multirow{2}{*}{ Treatments } & \multicolumn{4}{|c|}{ Pooled Mean data of two years (2015-16 and 2016-17) } \\
\hline & $\begin{array}{l}\text { Baby corn } \\
\text { yield } \\
\left(\mathrm{kg} \mathrm{ha}^{-1}\right)\end{array}$ & $\begin{array}{c}\mathrm{BEY} \\
\left(\mathrm{kg} \mathrm{ha}^{-1}\right)\end{array}$ & $\begin{array}{c}\text { System } \\
\text { Productivity } \\
\left(\mathrm{kg} \mathrm{ha}^{-1} \text { year }^{-1}\right)\end{array}$ & $\begin{array}{c}\text { System } \\
\text { Productivity } \\
\left(\mathrm{kg} \mathrm{ha}^{-1} \text { day }^{-1}\right)\end{array}$ \\
\hline \multicolumn{5}{|l|}{ Main treatments- (Kharif-Baby corn) } \\
\hline $\mathrm{T}_{1}-25 \% \mathrm{~N}$ through FYM + 75\% RDF & 1549 & 1954 & 3502 & 9.60 \\
\hline $\begin{array}{l}\mathrm{T}_{2-}-25 \% \mathrm{~N} \text { through FYM }+75 \% \mathrm{RDF}+\text { Azospirillum } \\
\text { and Bacillus megaterium @ } 5 \mathrm{~kg} \mathrm{ha}^{-1} \text { each }\end{array}$ & 1700 & 1996 & 3696 & 10.13 \\
\hline $\mathrm{T}_{3}-25 \% \mathrm{~N}$ through $\mathrm{VC}+75 \% \mathrm{RDF}$ & 1701 & 1921 & 3622 & 9.92 \\
\hline $\begin{array}{l}\mathrm{T}_{4}-25 \% \mathrm{~N} \text { through } \mathrm{VC}+75 \% \mathrm{RDF}+\text { Azospirillum } \\
\text { and Bacillus megaterium @ } 5 \mathrm{~kg} \mathrm{ha}^{-1} \text { each }\end{array}$ & 1970 & 1948 & 3918 & 10.73 \\
\hline $\mathrm{T}_{5}-100 \% \mathrm{RDF}$ & 1507 & 1629 & 3135 & 8.59 \\
\hline $\begin{array}{l}\mathrm{T}_{6}-100 \% \mathrm{RDF}+\text { Azospirillum } \text { and Bacillus } \\
\text { megaterium @ } 5 \mathrm{~kg} \mathrm{ha}^{-1} \text { each }\end{array}$ & 1680 & 1697 & 3377 & 9.25 \\
\hline $\mathbf{T}_{7}-$ Control (No fertilizer application) & 786 & 1486 & 2272 & 6.22 \\
\hline S.Em \pm & 40 & 26 & 44 & 0.12 \\
\hline C.D. $(P=0.05)$ & 123 & 81 & 134 & 0.37 \\
\hline \multicolumn{5}{|l|}{ Sub-treatments- (Rabi- hyacinth bean) } \\
\hline $\mathrm{S}_{1-100 \%} \mathrm{RDF}$ & 1589 & 1841 & 3431 & 9.40 \\
\hline $\mathrm{S}_{2}-\mathbf{7 5 \%} \mathrm{RDF}$ & 1501 & 1682 & 3183 & 8.72 \\
\hline $\begin{array}{l}\text { S3.100\% RDF + Bradyrhizobium @ } 500 \mathrm{~g} \mathrm{ha}^{-1} \text { Seed } \\
\text { treatment }\end{array}$ & 1611 & 1912 & 3523 & 9.66 \\
\hline $\begin{array}{l}\mathrm{S}_{4}-75 \% \text { RDF + Bradyrhizobium } @ 500 \mathrm{~g} \mathrm{ha}^{-1} \text { Seed } \\
\text { treatment }\end{array}$ & 1522 & 1784 & 3305 & 9.06 \\
\hline S.Em \pm & & 21 & 22 & 0.06 \\
\hline C.D. $(P=0.05)$ & & 61 & 64 & 0.17 \\
\hline
\end{tabular}

BEY: Baby corn equivalent yield 
Table.2 Effect of integrated nutrient management practices on gross returns, CoC, net returns and system profitability $\left(\mathrm{Rs} \mathrm{ha}^{-1} \mathrm{day}^{-1}\right)$ of baby corn-hyacinth bean cropping system

\begin{tabular}{|c|c|c|c|c|}
\hline \multirow[t]{2}{*}{ Treatments } & \multicolumn{4}{|c|}{ Pooled mean data of two years (2015-16 and 2016-17) } \\
\hline & $\begin{array}{l}\text { Grossreturns } \\
\left(\mathrm{Rs} \mathrm{ha}^{-1}\right)\end{array}$ & $\begin{array}{c}\mathrm{CoC} \\
\left(\mathrm{Rs} \mathrm{ha}^{-1}\right)\end{array}$ & $\begin{array}{l}\text { Netreturns } \\
\left(\text { Rs ha }^{-1}\right)\end{array}$ & $\begin{array}{l}\text { SystemProfitability } \\
\left(\text { Rs ha }^{-1} \text { day }^{-1}\right)\end{array}$ \\
\hline \multicolumn{5}{|l|}{ Main treatments- (Kharif-Baby corn) } \\
\hline 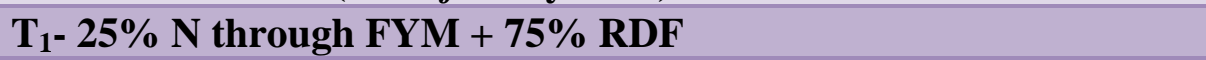 & 318453 & 84119 & 234335 & 642.0 \\
\hline $\begin{array}{l}\mathrm{T}_{2-}-25 \% \mathrm{~N} \text { through FYM }+75 \% \mathrm{RDF}+\text { Azospirillum and Bacillus } \\
\text { megaterium @ } 5 \mathrm{~kg} \mathrm{ha}^{-1} \text { each }\end{array}$ & 336243 & 85145 & 251099 & 687.9 \\
\hline 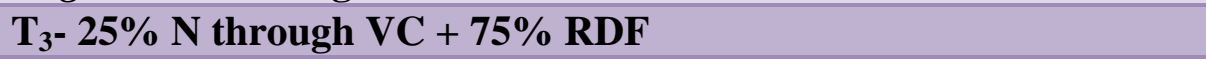 & 330957 & 86832 & 244126 & 668.8 \\
\hline $\begin{array}{l}\mathrm{T}_{4}-25 \% \mathrm{~N} \text { through } \mathrm{VC}+75 \% \mathrm{RDF}+\text { Azospirillum and Bacillus } \\
\text { megaterium @ } 5 \mathrm{~kg} \mathrm{ha}^{-1} \text { each }\end{array}$ & 358595 & 88346 & 270250 & 740.4 \\
\hline $\mathrm{T}_{5}-100 \% \mathrm{RDF}$ & 289254 & 76303 & 212952 & 583.4 \\
\hline $\begin{array}{l}\text { T}_{6^{-}} 100 \% \text { RDF + Azospirillum and Bacillus megaterium @ } 5 \mathrm{~kg} \mathrm{ha}^{-} \\
\text {each }\end{array}$ & 310219 & 77423 & 232797 & 637.8 \\
\hline $\mathbf{T}_{7}-$ Control (No fertilizer application) & 207749 & 66560 & 141190 & 386.8 \\
\hline S.Em \pm & 3714 & & 3714 & 10.2 \\
\hline C.D. $(P=0.05)$ & 11445 & & 11445 & 31.4 \\
\hline \multicolumn{5}{|l|}{ Sub-treatments- (Rabi- hyacinth bean) } \\
\hline $\mathrm{S}_{1}-100 \% \mathrm{RDF}$ & 319205 & 80877 & 232480 & 636.95 \\
\hline $\mathrm{S}_{2}-\mathbf{7 5 \%} \mathrm{RDF}$ & 306743 & 80340 & 211934 & 580.65 \\
\hline $\mathrm{S}_{3}-100 \%$ RDF + Bradyrhizobium @ $500 \mathrm{~g} \mathrm{ha}^{-1}$ Seed treatment & 324659 & 81077 & 240032 & 657.65 \\
\hline $\mathrm{S}_{4}-75 \%$ RDF + Bradyrhizobium @ $500 \mathrm{~g} \mathrm{ha}^{-1}$ Seed treatment & 315175 & 80405 & 222245 & 608.9 \\
\hline S.Em \pm & 1811 & & 1811 & 4.965 \\
\hline C.D. $(P=0.05)$ & 5169 & & 5169 & 14.15 \\
\hline
\end{tabular}




\section{References}

Anil Kumar, Thakur, K.S and Sandeep Manuja. 2002. Effect of fertility level on promising hybrid maize (Zea mays L.) under rainfed conditions of Himachal Pradesh. Indian Journal of Agronomy 47(4): 526-530.

Dadarwal, R.S., Jain, N.K and Singh, D. 2009. Integrated nutrient management in baby corn (Zea mays). Indian Journal of Agricultural Sciences 79: 1023-1025.

Datta, M and Banik, S. 1997. Comparative efficacy of different phosphatic fertilizers and phosphor bacterium (Bacillus firmus) on rice (Oryza sativa) in acid soil. Indian Journal of Agricultural Science. 67:545-547.

Ghosh, P.K., Das, Anup, Saha, R., Kharkrang, Enboklang, Tripathi, A.K., Munda, G.C and Ngachan, S.V. 2010. Conservation Agriculture towards Achieving Food Security in North East India. Current Science. 99(7): 915-921.

Gomez, K.A and Gomez, A.A.1984. Statistical procedures for agricultural research (2 edn.). John Wiley and sons, New York, 680p.

Kumar,A. 2008. Direct and residual effect of nutrient management in maize (Zea mays) - Wheat (Tritcum aestivum) cropping system. Indian Journal of Agronomy.53: 37- 41.

Mahajan, S., Kanwar, S.S., Kumar, P and Sharma, S.P. 2007. Long term effect of mineral fertilizers and amendments on microbial dynamics in an Alfisol of Western Himalayas. Indian Journal of Microbiology. 47: 86-89.

Panse, V.G and Sukhatme, P.V. 1978. Statistical Methods for Agricultural workers. 2: 197. Indian Council of Agricultural Research, New Delhi.

Ranjan, J.K., Ahmed, N., Das, B., Ranjan, P and Mishra, B.K. 2013.Green technology for production of baby corn (Zea mays L.) under north-west Himalayan conditions. International Journal of Chemical Technology Research. 5: 880-885.

Santhy, P., Muthuvel, P., Murugappan, V and Selvi, D. 1998. Long term effects of conditions cropping and fertilization on crop yields and soil fertility status. Journal of the Indian Society of Soil Science. 46(3): 391-395.

Singh, L., Verma, R.N.S and Lohia, S. S. 1980. Effect of continuous application of farm yard manure and chemical fertilizers on some soil properties. Journal of the Indian Society of Soil Science. 28(2): 170-172.

\section{How to cite this article:}

Preetham, R., K. Avil Kumar, A. Srinivas, A. Manohar Rao and Ram Prakash, T. 2019. Productivity and Profitability of Baby Corn-hyacinth Bean Cropping System as Influenced by Nutrient Management Practices. Int.J.Curr.Microbiol.App.Sci. 8(02): 2375-2382. doi: https://doi.org/10.20546/ijcmas.2019.802.276 